Faaza Naima, Ambang Aries Yudanto

\title{
Analisis Struktur Modal Optimal dalam rangka Pelaksanaan Proyek Strategis Nasional (Studi Kasus PT Wijaya Karya Tahun 2016 s.d. 2019)
}

\author{
Faaza Naima ${ }^{1)}$ \\ Politeknik Keuangan Negara STAN \\ Ambang Aries Yudanto ${ }^{2}$ \\ Politeknik Keuangan Negara STAN \\ ifafaaza@gmail.com ${ }^{1)}$,ariesyudanto@pknstan.ac.id ${ }^{2)}$
}

\begin{abstract}
Abstrak
Penelitian ini bertujuan untuk menjelaskan tentang penentuan struktur modal yang optimal dalam rangka pelaksanaan Proyek Strategis Nasional (PSN) PT Wijaya Karya Tbk. (WIKA) selama tahun 2016-2019. Tinjauan terhadap rasio solvabilitas WIKA periode 2016-2019, yaitu DER, DTCR, dan TIE WIKA masih berada di batas aman berdasarkan kebijakan manajemen dan rata-rata perusahaan sebanding, yaitu BUMN Konstruksi. Meskipun begitu, debt ratio WIKA rata-rata melebihi $50 \%$ dari aktiva dan rata-rata perusahaan sebanding. Terkati dengan struktur modal optimal, hasil penelitian menunjukkan bahwa kondisi optimal didapat pada saat nilai perusahaan tertinggi yaitu pada tahun 2019, dengan WACC sebesar 7.23\% dan nilai perusahaan Rp41,243,342,895,00. Meskipun bukan biaya modal rata-rata tertimbang terendah, tetapi faktor-faktor seperti peningkatan penerimaan bersih serta laba usaha terus mengalami peningkatan.
\end{abstract}

Kata Kunci: PSN, WIKA, Rasio Solvabilitas, WACC

\section{Pendahuluan}

Ketersediaan infrastruktur berkualitas merupakan salah satu faktor penentu daya saing suatu negara selain faktor kinerja ekonomi makro, efisiensi pemerintah, dan efisiensi usaha. Indonesia menempati peringkat 62 dari 140 negara untuk daya saing di bidang infrastruktur dalam The Global Competitiveness Report 2014-2015 oleh World Economy Forum (WEF). Dalam rangka peningkatan daya saing infrastruktur, dilakukan akselerasi pembangunan salah satunya yaitu dengan Proyek Strategis Nasional (PSN). PSN beserta daftar proyeknya secara hukum disahkan dengan Peraturan Presiden Nomor 3 Tahun 2016 tentang Percepatan Pelaksanaan PSN yang telah diubah menjadi Peraturan Presiden Nomor 56 Tahun 2018.

Berdasarkan publikasi BUMN dalam Kiprah BUMN Membangun Negeri (2017:30), BUMN menangani 96 dari 245 proyek awal. Dalam hal ini, sektor BUMN yang menjadi penggerak utamanya adalah BUMN Karya atau BUMN yang bergerak di bidang konstruksi. Salah satu BUMN konstruksi yang mengambil peranan adalah PT. Wijaya Karya (Persero) Tbk. Perusahaan yang memiliki kode emiten WIKA ini berpartisipasi dalam pelaksanaan 48 PSN hingga tahun 2019. Tentu sebagai salah satu BUMN Karya yang cukup strategis dan mendapatkan penyertaan modal negara, perlu diukur kinerja keuangannya supaya tetap efektif dan efisien (Hitt, 1995).

Kinerja keuangan salah satunya bisa dilihat melalui bagaimana struktur modal yang ada di dalam perusahaan. Pembentukan struktur modal akan mempengaruhi struktur kebijakan yang pada akhirnya akan mempengaruhi kemampuan pilihan strategis perusahaan (Jensen, 1986). Teori struktur modal bertujuan untuk menyediakan kerangka berpikir dalam 


\section{Faaza Naima, Ambang Aries Yudanto}

membentuk struktur modal yang optimal. Jika suatu tingkat risiko tertentu dapat memberikan nilai perusahaan terbesar, maka struktur permodalan tersebut dapat dikatakan optimal (Maftukhah, 2013). Perusahaan dalam menjalankan kegiatan usahanya membutuhkan modal yang didapat dari modal sendiri maupun modal pinjaman. Kebutuhan untuk memenuhi pembelanjaan jangka panjang perusahaan (modal) diharapkan dapat melalui pendanaan yang efisien yaitu dengan cara menentukan struktur modal yang optimal.

Pada tahun 2016, ekuitas WIKA mengalami peningkatan 129,89 kali dari ekuitas tahun 2015. Lalu tahun 2018, WIKA mengeluarkan pendanaan melalui global bond yang bernama Komodo Bond yang mengalami oversubscribed 2,5x dan Surat Berharga Perpetual I. Pada tahun 2019, WIKA berencana untuk mengeluarkan Surat Berharga Perpetual II. Perubahan proporsi struktur modal perusahaan setiap tahunnya pada saat pelaksanaan tersebut, tentunya akan mempengaruhi rasio solvabilitas perusahaan serta nilai perusahaan. Berdasarkan hal tersebut, Penulis tertarik untuk melakukan tinjauan terhadap rasio solvabilitas serta struktur modal yang optimal WIKA pada tahun 2016-2019. Periode tahun 2016 dipilih sebagai periode awal penelitian karena menggambarkan waktu dimana perusahaan mulai diamanatkan sebagai salah satu penggerak utama implementasi Proyek Strategis Nasional melalui Peraturan Presiden Nomor 3 Tahun 2016.

\section{Landasan Teori}

\section{Proyek Strategis Nasional}

Sesuai dengan Peraturan Presiden Nomor 3 Tahun 2016 tentang Percepatan Pelaksanaan Proyek Strategis Nasional, Proyek Strategis Nasional (PSN) adalah proyek yang dilaksanakan oleh Pemerintah, Pemerintah Daerah, dan/atau badan usaha yang memiliki sifat strategis untuk peningkatan pertumbuhan dan pemerataan pembangunan dalam rangka meningkatkan kesejahteraan masyarakat dan pembangunan daerah. Dalam perkembangannya, Pemerintah resmi menerbitkan Peraturan Presiden Nomor 56 Tahun 2018 tentang Perubahan Kedua atas Perpres Nomor 3 Tahun 2016 tentang Percepatan Pelaksanaan PSN. Perpres tersebut menggantikan Perpres Nomor 58 Tahun 217 tentang Perubahan atas Perpres Nomor 3 Tahun 2016. Adapun perubahan tersebut yaitu pada daftar PSN.

\section{Struktur Modal}

Mardiyanto (2009:257) menuturkan bahwa struktur modal adalah struktur keuangan dikurangi oleh utang jangka pendek. Utang jangka pendek tersebut tidak diperhitungkan karena jenis ini bersifat spontan atau berubah sesuai dengan perubahan tingkat penjualan. Sehingga, hubungan struktur keuangan dengan struktur modal diuraikan seperti dalam perbedaan berikut:

Struktur keuangan mencerminkan cara bagaimana perusahaan membiayai aktiva-aktivanya, dengan demikian struktur keuangan dapat dilihat pada keseluruhan sisi kanan dalam neraca yang terdiri dari utang jangka panjang dan jangka pendek, dan modal pemegang saham, sedangkan struktur modal adalah pembiayaan permanen yang mencerminkan perimbangan antara utang jangka panjang, saham preferen, dan modal pemegang saham.

Struktur modal dipengaruhi oleh faktor-faktor seperti, tingkat suku bunga, stabilitas dari earning, susunan dari aktiva, kadar teresiko dari aktiva, besarnya jumlah modal yang dibutuhkan, keadaan pasar modal, sifat manajemen, dan besarnya suatu perusahaan (Riyanto, 2013:297-300).

Franco Modigliani dan Merton H. Miller (1958), menyatakan bahwa nilai perusahaan tidak dipengaruhi oleh struktur modalnya dengan asumsi tidak realistis. Asumsi-asumsi tersebut di antaranya meniadakan biaya broker, pajak, biaya kebangkrutan, diferensiasi suku 


\section{Faaza Naima, Ambang Aries Yudanto}

bunga utang, asymetric information, serta laba sebelum bunga dan pajak tidak dipengaruhi oleh utang. Studi lanjutan dilakukan oleh MM pada tahun 1963 dengan hasil bahwa apabila terdapat pajak penghasilan perusahaan, maka penggunaan utang akan meningkatkan nilai perusahaan. Hal tersebut merupakan implikasi dari biaya bunga utang akan menjadi pengurang dalam pembayaran pajak (tax deductable expense). Penelitian tersebut baru melemahkan pendapat terkait peniadaan pajak dan belum mempertimbangkan financial distress atas kebangkrutan serta agency cost.

Brigham dan Daves (2004) dalam Aisjah (2012) menuturkan bahwa salah satu langkah untuk menganalisis struktur modal potensial yaitu dengan melakukan estimasi weight average cost of capital/WACC. Berdasarkan konsep cost of capital, perusahaan berusaha memiliki struktur modal yang optimal dalam arti bahwa struktur modal yang dapat meminimumkan biaya penggunaan modal rata-rata (WACC) (Riyanto, 2013:294). Hal ini sejalan dengan pendapat Sartono (2012:254), bahwa struktur modal yang optimal terjadi pada saat nilai perusahaan maksimal atau struktur modal yang mengakibatkan biaya rata-rata tertimbang turun.

Dalam tulisan ini menggunakan WACC untuk menunjukkan struktur modal yang optimal selama WIKA melakukan PSN dari tahun 2016-2019. Adapun penghitungan WACC adalah sebagai berikut.

$$
W A C C=\left[w_{d} x k_{d}(1-t)\right]+\left(w_{p s} x k_{p s}\right)+\left(w_{c e} x k_{e}\right)
$$

Biaya utang

$$
k_{i}=k_{d}(1-t)
$$

Biaya saham biasa dan laba ditahan

$$
\begin{aligned}
& k_{e}=\frac{D i}{P_{o}}+g \\
& g=R O E \times b
\end{aligned}
$$

Biaya saham preferen

$$
k_{p s}=\frac{d p}{n p}
$$

\section{Rasio Solvabilitas}

\section{a. Debt Ratio}

Rasio ini mengukur jumlah aktiva perusahaan yang dibiayai oleh utang atau modal yang berasal dari kreditur (Syamsudin, 2009:71).

$$
\text { Debt ratio }=\frac{\text { Total Liabilities }}{\text { Total Asset }}
$$

\section{b. Debt To Equity Ratio}

DER merupakan perbandingan antara utang jangka panjang yang dimiliki perusahaan dengan modal sendiri (Syamsudin, 2009:71). DER dalam jurnal ini merupakan variasi dari debt ratio (Damodaran, 2012) yang mana hanya menghitung utang jangka panjangnya sebagai numerator. 
INOBIS: Jurnal Inovasi Bisnis dan Manajemen Indonesia

Volume 03, Nomor 2, Maret 2020

Faaza Naima, Ambang Aries Yudanto

\section{c. Debt To Total Capitalization Ratio}

$$
\mathrm{DER}=\frac{\text { Long term debt }}{\text { Shareholder Equity }}
$$

Rasio ini mengukur berapa besar modal jangka panjang perusahaan dibiayai oleh kreditur (Syamsudin, 2009:71). Total capitalization dalam hal ini sama dengan struktur modal perusahaan yang terdiri atas utang jangka panjang dan ekuitas.

$$
\text { DTCR }=\frac{\text { Long term }- \text { debt }}{\text { Total Capitalization }}
$$

\section{d. Time Interest Earned}

Rasio ini mengukur kemampuan perusahaan dalam membayar kewajiban tetap berupa bunga dari utang.

$$
\mathrm{TIE}=\frac{\text { Earning before interest and tax }}{\text { Interest Expense }}
$$

\section{Nilai Perusahaan}

Sartono dalam Wangsawinangun, dkk. (2014:5) memaparkan bahwa nilai perusahaan dapat dihitung berdasarkan nilai pengembalian yang disyaratkan dari modal saham sendiri dan utang jangka panjang dengan menggunakan rumus berikut.

$$
V=\frac{E B I T(1-t)}{W A C C}+T D
$$

(Sartono, 2012:236)

(Atmaja, 2008:254)

$$
\begin{aligned}
S=V & =\frac{E B I T(1-t)}{K_{e} U} \\
V_{l} & =V_{U}+T D
\end{aligned}
$$

Hal tersebut sesuai dengan $M M$ Theory bila terdapat pajak yaitu value of firm merupakan hasil dari kuantifikasi value if all-equity-financed dengan present value tax shield. Brealey dan Myers (1991) dalam Sawir (2004) mengatakan bahwa adanya pajak perorangan mengurangi keuntungan pajak yang berkaitan dengan utang perusahaan.

Selama pajak perorangan atas penghasilan saham lebih kecil daripada pajak perorangan atas penghasilan utang, keuntungan pajak bersih atas utang akan positif. Akibatnya, nilai perusahaan akan meningkat dengan utang yang lebih besar, tetapi tidak secepat apabila tidak ada pajak perorangan atau pajak perorangan atas penghasilan saham dan utang sama.

Meskipun begitu, MM dalam Sawir (2004) berpendapat bahwa perusahaan hendaknya berkerja pada target debt ratio sebagai salah satu faktor yang menentukan kebijakan pendanaan.

\section{Metode Penelitian}

Metode penelitian yang akan digunakan adalah studi kepustakaan dan penelitian deskriptif. Zed (2003:3) mendefinisikan bahwa studi pustaka merupakan serangkaian kegiatan yang berkenaan dengan metode pengumpulan data pustaka, membaca, dan mencatat serta 
mengolah bahan penelitian. Sedangkan penelitian deskriptif, menurut Arikunto (2006:30) merupakan penelitian yang bersifat menjelaskan atau menerangkan suatu peristiwa. Penelitian deskriptif tidak dimaksudkan untuk menguji hipotesis tertentu, melainkan hanya untuk memberikan gambaran terdapat adanya suatu variabel terkait data dan informasi dari laporan tahunan serta melakukan pengolahan data keuangan WIKA periode tahun 2016-2019.

\section{Pembahasan}

1. Rasio Solvabilitas Perusahaan

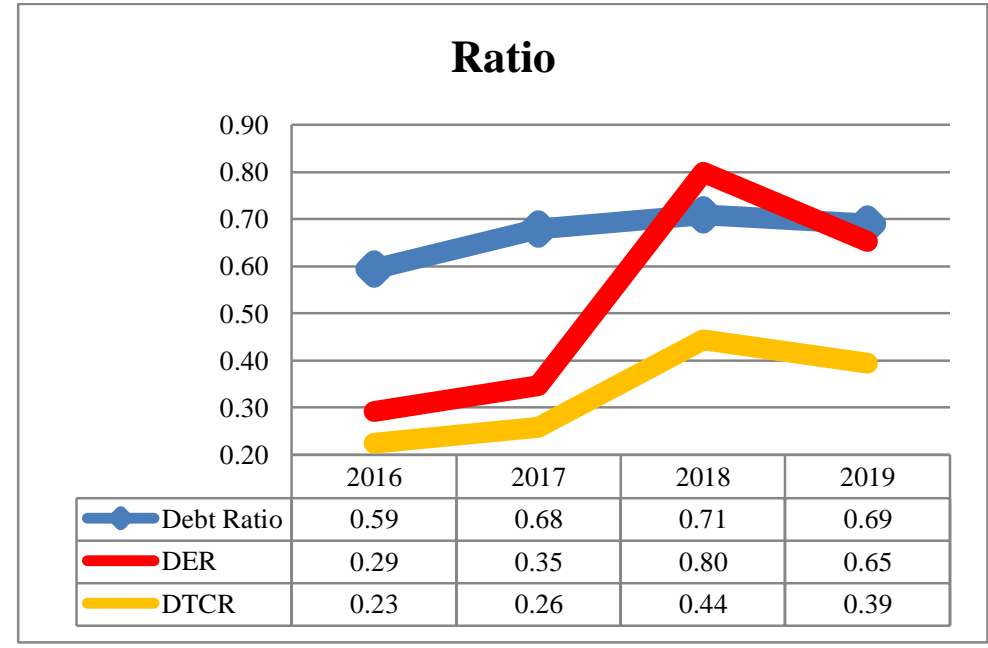

Gambar 1. Rasio Solvabilitas-Debt Ratio, DER, DTCR

\section{a. Debt ratio}

Referensi: Diolah Penulis

Gambar 1 menunjukkan pembiayaan aktiva WIKA dari utang selama tahun 20162019 tidak mengalami perubahan yang signifikan. Proporsi utang dalam pembiayaan aktiva WIKA lebih besar daripada pembiayaan aktiva WIKA yang bersumber dari ekuitas, yaitu 59\% aset WIKA dibiayai dari utang pada tahun 2016. Proporsi tersebut meningkat $9 \%$ dari tahun 2015. Peningkatan jumlah utang pada tahun 2016 tersebut diiringi dengan meningkatnya kontrak baru yang ditangani WIKA.

Pada tahun 2016, pertumbuhan kontrak baru WIKA mengalami peningkatan $117.13 \%$ dan kontrak dihadapi sebesar $71.65 \%$ dari tahun 2015. Hal ini tidak lepas dari percepatan pembangunan yang dilakukan Pemerintah dalam Instruksi Presiden Nomor 1 Tahun 2016 dan Perpres Nomor 3 tahun 2016. Namun, peningkatan utang tidak sebanding dengan besarnya peningkatan kontrak baru. Terbukti peningkatan utang pada tahun 2016 hanya $31.30 \%$ dari tahun 2015. Hal ini disebabkan, pada tahun 2016, WIKA mendapatkan Penyertaan Modal Negara sebesar Rp4 triliun dan melaksanakan privatisasi dengan metode Right Issue atau Hak Memesan Efek Terlebih Dahulu (HMETD) yang memperoleh dana publik sebesar Rp2.1 triliun.

Berdasarkan Laporan Tahunan Konsolidasian WIKA tahun 2016, perolehan dana tersebut ditempatkan dalam proyek prioritas, proyek strategis, PSN, dan modal kerja Perseroan. Penempatan dana pada PSN di antaranya, Jalan Tol Soreang-Pasirkoja sebesar 35,8 miliar, Jalan Tol Manado-Bitung sebesar Rp14,40 miliar, serta Jalan Tol Samarinda-Balikpapan sebesar Rp20,10 miliar. Pada tahun 2017, proporsi utang meningkat 66.79\% meskipun kontrak baru mengalami penurunan $22 \%$ dari tahun 2016. Namun, kontrak baru yang dihadapi mengalami kenaikan $103 \%$ dibanding pada tahun 2015. Kondisi ini dikarenakan, pada akhir 


\section{Faaza Naima, Ambang Aries Yudanto}

tahun 2015 hingga tahun 2016 terjadi peningkatan pengikatan komitmen pada kontrak-kontrak baru. Adapun kontrak baru tersebut 22.23\% merupakan proyek Pemerintah dan $14.09 \%$ proyek BUMN.

Pada tahun 2016, WIKA dapat menyelesaikan proyek-proyek yang nilai kontraknya tidak terlalu besar, seperti Pos Lintas Batas Entikong (Rp138,628 miliar) dan Pos Lintas Batas Aruk (Rp119,209 miliar). Sedangkan pada tahun 2017, mulai melakukan konstruksi Jalan Tol Serang-Panimbang, Jalan Tol Balikpapan-Samarinda, Jalan Tol Gempol-Pasuruan, Jalan Tol Cengkareng-Batu Ceper-Kunciran, hingga proyek High Speed Railway Jakarta-Bandung yang bernilai Rp15 triliun. Hal ini mengakibatkan kebutuhan dana terutama operasional jangka pendek pada tahun 2017 tersebut yang dibiayai dari utang Perseroan.

Pada tahun 2018, peningkatan utang hanya $35.3 \%$, lebih rendah dari peningkatan utang pada tahun 2017. Pada tahun tersebut, baik kontrak baru maupun kontrak dihadapi mengalami peningkatan masing-masing $19.24 \%$ dan $15.82 \%$ dari tahun sebelumnya. Adapun pendanaan pada tahun 2018, WIKA melakukan transaksi restrukturisasi utang melalui Global IDR Bond (Komodo Bond) dan restrukturisasi modal melalui penerbitan Surat Berharga Perpetual (SBP). Melalui penerbitan Komodo Bond, terhimpun dana sebesar Rp5,4 triliun yang tercatat sebagai pinjaman jangka menengah (jatuh tempo dalam 3 tahun) atau Liabilitas Jangka Panjang Atas Utang Bank Setelah Dikuragi Bagian Yang Jatuh Tempo Dalam Satu Tahun pada neraca. Sedangkan melalui penerbitan SBP Tahap I terhimpun dana Rp600 miliar yang tercatat dalam ekuitas sebesar Rp597,6 miliar. Meskipun SBP atau perpetual bond merupakan utang tanpa waktu jatuh tempo, surat berharga ini memiliki kecenderungan karakteristik seperti ekuitas.

Pada tahun 2019, setelah meningkatnya instrumen keuangan hybrid bertajuk Global Bond di Indonesia, Otoritas Jasa Keuangan (OJK) menerbitkan Peraturan OJK RI Nomor 30/PJOK.04/2019 tentang Penerbitan Efek Bersifat Utang Dan/Atau Sukuk Yang Dilakukan Tanpa Melalui Penawaran Umum. Di dalamnya mengatur mekanisme resmi penerbitan SBP dan bukan memberikan kategorisasi penggolongan SBP. Adapun WIKA dalam Catatan Laporan Keuangan (CaLK) Konsolidasian (2019:27) menyatakan bahwa SBP diklasifikasikan sebagai ekuitas dikarenakan tidak memiliki kewajiban kontraktual untuk menyerahkan atau menukar aset keuangan atau liabilitas keuangan dengan pemegang perpetual securities dalam kondisi yang berpotensi tidak menguntungkan Grup. Proporsi utang WIKA terhadap aktiva yang dimiliki mengalami penurunan sebesar 2\% daripada tahun 2018. Adapun peningkatan jumlah utang dalam neraca hanya 2\% dibandingkan dengan jumlah utang pada tahun 2018 . Berdasarkan evaluasi perbandingan target dan realisasi WIKA 2019, terdapat beberapa target Rencana Kerja dan Anggaran Perusahaan (RKAP) 2019 yang belum tercapai, di antaranya kontrak baru dan kontrak dihadapi. Beberapa penyebabnya yaitu disebabkan menurunnya nilai kontrak baru yang diperoleh Perseroan tahun 2019 akibat tertundanya lelang di berbagai proyek. Selain itu, penurunan permintaan di sektor realty \& property di tahun tersebut dikarenakan melambatnya ekonomi global. Kondisi itu juga ditambah dengan pesta demokrasi tahun 2019 yang menyebabkan beberapa proyek konstruksi mengalami penundaan. 
INOBIS: Jurnal Inovasi Bisnis dan Manajemen Indonesia

Volume 03, Nomor 2, Maret 2020

Faaza Naima, Ambang Aries Yudanto

b. Debt to equity ratio (DER)

Tabel 1. Struktur Keuangan WIKA 2016-2019

(disajikan dalam ribuan Rupiah)

\begin{tabular}{|l|r|r|r|r|}
\hline \multicolumn{1}{|c|}{ 31 Desember } & $\underline{\mathbf{2 0 1 6}}$ & $\underline{\mathbf{2 0 1 7}}$ & $\underline{\mathbf{2 0 1 8}}$ & $\underline{\mathbf{2 0 1 9}}$ \\
\hline $\begin{array}{l}\text { Liabilitas Jangka } \\
\text { Pendek }\end{array}$ & $14,909,016,696$ & $25,975,617,297$ & $28,251,951,385$ & $30,349,456,945$ \\
\hline $\begin{array}{l}\text { Liabilitas Jangka } \\
\text { Panjang }\end{array}$ & $3,708,198,703$ & $5,076,332,392$ & $13,762,735,289$ & $12,545,657,222$ \\
\hline Total Liabilitas & $18,617,215,399$ & $31,051,949,689$ & $42,014,686,674$ & $42,895,114,167$ \\
\hline Ekuitas & $12,737,989,291$ & $14,631,824,613$ & $17,215,314,565$ & $19,215,732,987$ \\
\hline $\begin{array}{l}\text { Total Liabilitas dan } \\
\text { Ekuitas }\end{array}$ & $31,355,204,690$ & $45,683,774,302$ & $59,230,001,239$ & $62,110,847,154$ \\
\hline
\end{tabular}

Referensi: Diolah dari Laporan Keuangan Tahunan Konsolidasian WIKA 2016-2019

Selama pelaksanaan PSN dari tahun 2016-2019, WIKA sempat mengalami peningkatan utang jangka panjang yang cukup tajam pada tahun 2018 , yaitu sebesar $17 \%$ dari tahun 2017. Sedangkan pada tahun 2017 dan 2019, utang jangka panjang WIKA mengalami penurunan masing-masing sebesar $4 \%$ dari tahun sebelumnya.

Tabel 2. Proporsi Utang WIKA 2016-2019

\begin{tabular}{|l|l|l|l|l|}
\hline 31 Desember & $\underline{\mathbf{2 0 1 6}}$ & $\underline{\mathbf{2 0 1 7}}$ & $\underline{\mathbf{2 0 1 8}}$ & $\underline{\mathbf{2 0 1 9}}$ \\
\hline Liabilitas Jangka Pendek & $80 \%$ & $84 \%$ & $67 \%$ & $71 \%$ \\
\hline Liabilitas Jangka Panjang & $20 \%$ & $16 \%$ & $33 \%$ & $29 \%$ \\
\hline
\end{tabular}

Referensi: Diolah dari Laporan Keuangan Tahunan Konsolidasian WIKA 2016-2019

Jika ditinjau dari debt ratio sebelumnya, proporsi utang WIKA berada di atas 50\% dari aktiva Perseroan. Namun, dalam Tabel 2 dapat kita lihat bahwa proporsi utang jangka pendek lebih dominan dibandingkan dengan utang jangka panjang setiap tahunnya.

Debt ratio atau rasio utang jangka panjang terhadap ekuitas mengalami fluktuasi dari $29 \%$, kemudian naik menjadi 35\% dan $80 \%$ pada tahun-tahun berikutnya, lalu terakhir turun menjadi $60 \%$ pada tahun 2019. Pada setiap tahunnya, ekuitas mengalami peningkatan secara proporsional, sedangkan utang jangka panjang mengalami penurunan sekali pada tahun 2019 .

Pada tahun 2016, solvabilitas WIKA menunjukkan peningkatan seiring dengan adanya aktivitas right issue dan mendapatkan dana segar dari PMN dengan total Rp6,1 triliun. Perolehan keduanya menambah ekuitas Perseroan pada bagian Tambahan Modal Disetor. Ekuitas WIKA meningkat 129.84\% dari tahun 2015, dengan komposisi terbesar Tambahan Modal Disetor mencapai 52.34\%. Sedangkan peningkatan Tambahan Modal Disetor dibandingkan dengan tahun 2015 , yaitu sebesar $813.86 \%$. Hal ini pula yang menyebabkan rasio total utang terhadap ekuitas mengalami perbaikan dari 3.24 kali menjadi 1.64 kali pada tahun 2016.

Pada tahun 2017, utang jangka panjang mengalami peningkatan, tetapi proporsinya dalam total utang mengalami penurunan. Penyebab kenaikan utang yaitu bagian Biaya Yang Masih Harus Dibayar pada utang jangka pendek sebagai biaya yang belum ditagihkan oleh pihak ketiga maupun tenaga kerja proyek sehubungan dengan pelaksanaan pekerjaan di lapangan. Hal ini sesuai dengan kondisi bahwa pada tahun 2017 merupakan waktu awal 


\section{Faaza Naima, Ambang Aries Yudanto}

dimulainya konstruksi fisik atas proyek-proyek yang bernilai kontrak besar, seperti High Speed Railway Jakarta-Bandung yang bernilai Rp15 triliun. Kebutuhan dana jangka pendek untuk aktivitas operasi di lapangan menyebabkan kenaikan utang jangka pendek sebagai modal kerja. Adapun pada tahun 2016 yang mana tahun-tahun konstruksi proyek yang bernilai tidak terlalu besar dan sebagai persiapan proyek-proyek besar di tahun 2017, mengalami peningkatan modal kerja tertinggi pada bagian Pinjaman Jangka Pendek. Peningkatan Pinjaman Jangka Pendek dalam utang jangka pendek tersebut mencapai $285.64 \%$ dari tahun 2015. Pinjaman Jangka Pendek tersebut terkait aktivitas persiapan proyek-proyek yang bersifat modal kerja.

Setelah melakukan perbaikan struktur keuangan pada tahun 2016, WIKA melakukan penguatan balance sheet dengan meningkatkan baik total aset maupun ekuitas pada tahun 2018 . Ekuitas mengalami peningkatan $17.66 \%$ dari tahun 2017 yang mana kontribusi terbesar berasal dari penerbitan SBP yang bernilai bersih Rp597,6 triliun. Sedangkan utang jangka panjang juga mengalami peningkatan $171.11 \%$ dibandingkan tahun 2017. Peningkatan utang jangka panjang tersebut berasal dari kenaikan Pinjaman Jangka Menengah sebesar 508.46\% dari tahun 2017. Adapun Pinjaman Jangka Menengah yaitu berupa Komodo Bond dan Medium Term Notes lainnya yaitu masing-masing digunakan untuk membiayai proyek investasi dan infrastruktur serta modal kerja pembangunan kawasan realti. Adapun PSN yang dibiayai dengan Komodo Bond, salah satunya yaitu High Speed Railway Jakarta-Bandung.

Utang jangka panjang tahun 2018 mengalami kenaikan proporsi terhadap jumlah utang, yaitu $33 \%$ dari total utang. Hal ini juga meningkatkan DER WIKA yaitu sebesar 0.8 kali ekuitas. Lalu pada tahun 2019, baik DER maupun utang jangka panjang mengalami penurunan masing-masing sebesar $15 \%$ dan 4\% dibandingkan tahun 2018. Total utang mengalami kenaikan 2\% dengan kontribusi terbesar pada utang jangka pendek bagian utang usaha atas optimalisasi penggunaan fasilitas perbankan seperti supply chain financing (SCF). Sedangkan penurunan utang jangka panjang disebabkan beberapa pinjaman jangka panjang pada keuangan entitas anak yang sudah jatuh tempo di tahun 2019. Selain itu beberapa utang jangka panjang pada entitas induk yang jatuh tempo pada akhir tahun 2018, seperti pinjaman dari PT Bank Mandiri (Persero) Tbk. (2015), IKB Deutsche Industrie Bank. AG (2010), PT Bank Tabungan Negara (Persero) Tbk., serta PT Bank Rakyat Indonesia (Persero) Tbk. (2013) pada awal tahun 2019.

\section{c. Debt to total capitalization ratio (DTCR)}

DTCR mengalami fluktuasi selama periode tahun 2016-2019. Pada rasio ini menunjukkan proporsi utang jangka panjang dalam suatu struktur modal. Adapun penentuan total capitalization merupakan hasil penjumlahan dari seluruh struktur modal yang digunakan, yaitu liabilitas jangka panjang dan ekuitas dalam Tabel 1. Total capitalization mengalami peningkatan setiap tahunnya, yang mana peningkatan tertinggi terjadi pada tahun 2018, yaitu meningkat $57.19 \%$ dari tahun 2017. Pada setiap tahunnya, secara konsisten proporsi ekuitas lebih besar daripada utang jangka panjang.

Ekuitas mengalami peningkatan dari tahun ke tahun, sedangkan utang jangka panjang mengalami penurunan sekali pada tahun 2019. Perubahan struktur modal tersebut tidak lepas dari kebijakan struktur modal Perseroan setiap tahunnya.Dalam rangka pengembangan usaha pada tahun 2016, WIKA melakukan kebijakan struktur keuangan dengan menambahkan utang jangka panjang dan jangka pendek masing-masing $11.91 \%$ dan $37.83 \%$ serta ekuitas sebesar $129.84 \%$ dari tahun sebelumnya. Peningkatan tajam ekuitas berasal dari aktivitas right issue dan penerimaan PMN. Perusahaan juga melakukan pantauan terhadap likuiditas dan ekuitas. Pada tahun 2016, perbandingan kedua aktivitas tersebut menunjukkan angka 1.49:1, sedangkan pada tahun 2015 yaitu 2.60:1. Hal tersebut menunjukkan bahwa perubahan kebijakan 
manajemen atas struktur keuangan, yaitu dengan menambah liabilitas Perseroan. Dari Tabel 2, kita ketahui bahwa proporsi utang jangka panjang pada struktur modal yaitu sebesar $23 \%$.

Pada tahun 2017, proporsi utang jangka panjang dalam struktur modal meningkat 3\% menjadi 26\%. Hal tersebut sejalan dengan ulasan dalam Laporan Tahunan Konsolidasian WIKA yang menyatakan bahwa penggunaan liabilitas sebagai sumber modal menjadi kebijakan atas struktur keuangannya. WIKA melakukan penambahan utang jangka panjang, utang jangka pendek, serta ekuitas masing-masing 74.23\%, 36.89\%, dan $14.87 \%$. Utang jangka panjang mengalami peningkatan yang signifikan bersamaan dengan menurunnya peningkatan ekuitas. Utang jangka panjang mengalami kenaikan yang signifikan pada Liabilitas atas Utang Bank Jangka Panjang yang disebabkan oleh penerimaan pinjaman jangka menengah dan jangka panjang, seperti MTN V WIKA Realty 2017, MTN VI WIKA Realty 2017, BTN 2017, Sindikasi BNI-Mandiri 2017, CIMB 2017, dan China Construction 2017. Namun peningkatan utang jangka panjang tidak lebih besar dibandingkan utang jangka pendek dalam proporsi jumlah utang. Hal ini dikarenakan terdapat beberapa pinjaman baik jangka pendek maupun jangka panjang yang jatuh tempo pada tahun tersebut. Selain itu, jumlah utang jangka pendek meningkat seiring peningkatan modal kerja sebagai pendanaan jangka pendek atas aktivitas konstruksi yang besar di tahun tersebut.

Pada tahun 2018, DTCR mengalami peningkatan yang signifikan menjadi $44 \%$ dibandingkan tahun 2017. Peningkatan utang jangka panjang berasal dari Komodo Bond yang tercatat menambah utang jangka panjang dalam bagian Liabilitas Jangka Panjang atas Utang Bank sebagai Pinjaman Jangka Menengah bertenor 3 tahun. Obligasi berdenominasi Rupiah sebesar Rp5,4 triliun tersebut dikenakan biaya bunga 7.7\% per tahun dan akan jatuh tempo pada bulan Januari 2021. Selain itu, peningkatan juga terjadi pada bagian ekuitas yang berasal dari penerbitan Surat Berharga Perpetual pada tanggal 27 Desember 2018 yang mencapai Rp600 miliar dengan imbal hasil $10.5 \%$ per tahun ditambah step-up rate. Peningkatan jumlah struktur modal baik dari sisi utang maupun ekuitas tersebut meningkatkan rasio utang jangka panjang terhadap struktur modal yaitu $44 \%$.

Pada tahun 2019 terjadi penurunan proporsi utang jangka panjang terhadap struktur modal sebesar 5\%. Pada tahun tersebut, utang jangka panjang mengalami penurunan, tetapi tidak dengan ekuitas yang meningkat $11.62 \%$ dari tahun 2018. Kenaikan ekuitas disebabkan peningkatan pada bagian Saldo Laba yang tumbuh 33\% dari tahun 2018. Hal tersebut merupakan kontribusi dari laba bersih yang mengalami peningkatan sebesar $26.43 \%$ dibandingkan tahun 2018. Meskipun mengalami penurunan dalam perolehan kontrak baru dan penundaan beberapa proyek dampak dari tertundanya lelang dan ketidakstabilan perekonomian global, WIKA melanjutkan langkah ekspansi ke luar negeri dengan metode selective market. Selective market yang dimaksud dalam hal ini, yaitu WIKA hanya mengambil proyek dengan nilai Rp200 miliar ke atas, berfokus pada pasar domestik dari Pemerintah, BUMN, dan swasta, tidak lagi melakukan proyek-proyek pemerintah daerah kecuali proyek Pemerintah Provinsi DKI Jakarta, dan berfokus pada pasar luar negeri yang sudah dikuasai.

\section{d. $\quad$ Time interest earned (TIE)}

Berdasarkan Tabel 1, struktur keuangan WIKA menitikberatkan penggunaan utang sebagai sumber modal. Kebijakan manajemen atas penggunaan sumber dana tentunya didasarkan untuk melindungi Perseroan dalam mempertahankan kelangsungan usaha sehingga dapat memberikan imbal hasil bagi pemegang saham dan memberikan manfaat bagi pemangku kepentingan lainnya.

Dalam laporan posisi keuangan WIKA, tidak tercantum secara eksplisit beban bunga yang dibayarkan setiap tahunnya. Berdasakan PSAK 01, salah satu pos yang wajib disajikan 


\section{Faaza Naima, Ambang Aries Yudanto}

dalam laporan laba rugi dan penghasilan komprehensif lain konsolidasian, yaitu biaya keuangan. Biaya keuangan, termasuk di dalamnya biaya bunga dan biaya lain yang ditanggung perusahaan sehubungan dengan peminjaman dana dan biaya keuangan lainnya yang terjadi dari transaksi instrumen keuangan.

Biaya sehubungan dengan peminjaman dana meliputi bunga pinjaman, diskonto dan premium terkait pinjaman, biaya tambahan yang terjadi yang terkait dengan perolehan pinjaman, beban keuangan dalam sewa pembiayaan, biaya imbalan karena jaminan pengembalian utang, ataupun selisih kurs dari transaksi terkait pinjaman. Meskipun tidak dicantumkan secara eksplisit, tetapi pembayaran bunga pinjaman muncul di dalam pos arus kas dari aktivitas operasi laporan arus kas Perseroan.

Pos Pembayaran Bunga Pinjaman dalam laporan arus kas Perseroan nilainya sama dengan pos Beban dari Pendanaan dalam laporan laba rugi Perseroan. Namun, pada tahun 2018, terdapat perbedaan angka yaitu Rp998,921,933,00 dalam Pembayaran Bunga Pinjaman dan Rp972,528,279,00. Tidak terdapat catatan terhadap kedua pos tersebut di dalam setiap CaLK konsolidasian WIKA setiap tahunnya. Dalam hal ini, Penulis menggunakan interest expense dari pinjaman berdasarkan Beban dari Pendanaan dalam laporan laba rugi WIKA.

Tabel 3. Ikhtisar Laba Rugi (Parsial) WIKA 2016-2019

(disajikan dalam ribuan Rupiah)

\begin{tabular}{|l|r|r|r|r|}
\hline & \multicolumn{1}{|c|}{$\underline{\mathbf{2 0 1 6}}$} & \multicolumn{1}{c|}{$\underline{\underline{\mathbf{2 0 1 7}}}$} & \multicolumn{1}{c|}{$\underline{\underline{\mathbf{2 0 1 8}}}$} & \multicolumn{1}{c|}{$\underline{\mathbf{2 0 1 9}}$} \\
\hline $\begin{array}{l}\text { Laba sebelum Pajak } \\
\text { (EBT) }\end{array}$ & $1,295,239,236$ & $1,462,391,358$ & $2,358,628,934$ & $2,789,255,688$ \\
\hline Beban dari Pendanaan & $435,314,128$ & $677,973,460$ & $972,528,679$ & $884,252,228$ \\
\hline Laba Usaha (EBIT) & $1,730,553,364$ & $2,140,364,818$ & $3,331,157,613$ & $3,673,507,916$ \\
\hline
\end{tabular}

Referensi: Diolah dari Laporan Keuangan Konsolidasian WIKA 2016-2019

Penghitungan Laba Usaha dilakukan dengan menjumlahkan kembali Beban dari Pendanaan dengan Laba Sebelum Pajak. Berdasarkan Tabel 3, Laba sebelum Pajak WIKA mengalami peningkatan setiap tahunnya. Sedangkan Beban dari Pendanaan mengalami fluktuasi yang proporsional mengikuti jumlah utang yang digunakan. Pada tahun 2019, jumlah utang mengalami peningkatan $2 \%$, tetapi utang jangka panjang mengalami penurunan $5 \%$ dari tahun 2018.

Pada tahun 2016, dengan restrukturisasi struktur keuangan, WIKA mampu membiayai 3.98 kali dari bunga yang dibayarkan. Artinya, WIKA mampu melakukan pembayaran atas kewajiban-kewajiban pinjaman 3.98 kali dari biaya bunga pada tahun tersebut.

Pada tahun 2017, dengan padatnya proyek konstruksi, WIKA mampu membiayai 3.16 kali dari bunga yang dibayarkan. Artinya, WIKA mampu melakukan pembayaran atas kewajiban-kewajiban pinjaman 3.16 kali dari biaya bunga pada tahun tersebut. Penurunan ini dikarenakan Beban Lain-Lain yang mencapai Rp295,507,893,000,00. Beban Lain-Lain tersebut merupakan beban usaha yang meliputi Beban Penurunan Nilai Piutang Rp106,899,705,000,00 dan Lain-Lain Neto Rp188,608,188,000,00.

Peningkatan Laba Sebelum Pajak pada tahun 2018 dikarenakan adanya pertumbuhan pada laba kotor $25.33 \%$. Hal ini tidak lepas dari penguatan balance sheet WIKA baik dari aset maupun sumber pendanaannya, yaitu Komodo Bond dari sisi liabilitas dan SBP dari sisi ekuitas. Penguatan dari sumber pendanaan tersebut dibutuhkan WIKA dalam menghadapi kenaikan kontrak baru dan kontrak yang dihadapi pada tahun 2018. Dampak dari peningkatan jumlah utang di tahun 2018, yaitu meningkatnya interest expense sebesar 43\%. Dengan pencatatan Laba Bersih sebesar Rp3,331,157,613,000,00, WIKA mampu membiayai 3.43 kali 


\section{Faaza Naima, Ambang Aries Yudanto}

biaya bunga Perseroan. Atau dapat diartikan, setiap rupiah bunga utang baik jangka pendek maupun jangka panjang dijamin oleh keuntungan Rp3.43,00. Sehingga dalam hal ini, WIKA masih mampu untuk membayar biaya bunga tambahan apabila berencana untuk melakukan pinjaman melalui utang lagi.

Pada tahun 2019, kembali memperbaiki kemampuan membayar bunga pinjamannya dengan menunjukkan rasio sebesar 4.15 kali bunga yang dibayarkan. Kemampuan yang lebih baik dibandingkan tahun-tahun sebelumnya, meskipun berada di masa penuh tantangan, yaitu penurunan kontrak baru dan penundaan berbagai proyek.

\section{Tinjauan Struktur Modal}

\section{a. Struktur modal WIKA 2016-2019}

Kebijakan struktur keuangan WIKA mengalami perubahan setiap tahunnya. Komposisi struktur keuangan WIKA pada tahun 2016, yaitu 59.81\% berasal dari utang dan $40.19 \%$ berupa ekuitas. Komposisi tersebut mengalami perubahan, yaitu peningkatan $31.30 \%$ atas utang dan $129.84 \%$ atas ekuitas dibandingkan dengan tahun 2015. Sedangkan struktur modal WIKA mengalami peningkatan dalam utang jangka panjang, yaitu $11.91 \%$ dibandingkan tahun 2015 . Utang jangka panjang memiliki porsi $23 \%$ dari struktur modal, sehingga dapat kita lihat bahwa proporsi utang jangka pendek lebih besar sebagai bentuk pemenuhan kebutuhan modal kerja.

Pada tahun 2016, kebijakan struktur keuangan WIKA menitikberatkan pada perbandingan likuiditas dan ekuitas sebagai konsentrasi Perseroan di tahun tersebut. Hal ini dikarenakan, pada tahun sebelumnya, jumlah total utang terhadap ekuitas (DER) mencapai 3.24\%. Padahal, rasio tersebut menjadi salah satu kewajiban dalam persyaratan peminjaman dana pada umumnya. Misalkan, dalam Pinjaman Jangka Panjang dari Pinjaman Sindikasi-Bank of Tokyo-Mitsubishi UFJ (BTMU), mensyaratkan bahwa Perusahaan diharuskan mematuhi batasan untuk mempertahankan rasio utang terhadap ekuitas maksimal 3.5 kali. Begitu pula PT Bank Tabungan Negara (Persero) Tbk. yang mensyaratkan rasio total utang terhadap ekuitas maksimal $500 \%$ atau 5 kali.

Setelah melakukan restrukturisasi rasio jumlah total utang terhadap ekuitas menjadi 1.64\% pada tahun 2016 dari PMN dan right issue, WIKA memilih kebijakan untuk menitikberatkan penggunaan utang sebagai sumber modalnya pada tahun 2017. Utang mendapatkan porsi 67\% dalam struktur keuangan WIKA, meningkat 6.19\% dari tahun 2016 . Sedangkan proporsi ekuitas mengalami penurunan menjadi $32 \%$. Penambahan utang jangka panjang dan jangka pendek masing-masing mengalami peningkatan sebesar $74.23 \%$ dan $36.89 \%$ dibandingkan tahun 2016. Sedangkan ekuitas meningkat $14.87 \%$ dibandingkan tahun 2016, yang mana angka tersebut jauh lebih rendah dari peningkatan tahun sebelumnya.

Pada tahun 2018, WIKA masih menggunakan utang sebagai komposisi terbesar sumber modalnya. Proporsi utang meningkat menjadi $70.93 \%$ dibersamai dengan penurunan ekuitas menjadi 29.07\%. Hal ini dikarenakan SBP sejumlah Rp600 miliar sebagai ekuitas tidak lebih besar dari penerbitan Komodo Bond sebagai utang yang mencapai Rp5,4 triliun. Adapun utang jangka panjang meningkat tajam baik ditinjau dari segi proporsi dalam utang maupun dibandingkan dengan tahun 2017. Hal ini juga dikarenakan Komodo Bond yang merupakan pinjaman jangka menengah bertenor 3 tahun diklasifikasikan sebagai komponen utang jangka panjang.

Pada tahun 2019, utang jangka panjang WIKA mengalami penurunan, meskipun total utang mengalami peningkatan. Hal ini disebabkan oleh beberapa pinjaman jangka panjang pada keuangan entitas anak yang sudah jatuh tempo di tahun 2019. Hal ini menyebabkan proporsi utang dalam struktur keuangan mengalami penurunan menjadi $69 \%$ dan ekuitas meningkat menjadi $31 \%$. 


\section{Faaza Naima, Ambang Aries Yudanto}

Pada tahun 2019 tersebut, WIKA masih menggunakan utang sebagai sumber modalnya. Batasan dalam pengelolaan utang, WIKA mematuhi peraturan pajak yang berlaku, yaitu Peraturan Menteri Keuangan Nomor 169/PMK.10/2015 tentang Penentuan Besarnya Perbandingan antara Utang dan Modal Perusahaan untuk Keperluan Penghitungan Pajak Penghasilan. Di dalamnya, terdapat rasio maksimum atas jumlah utang terhadap ekuitas yaitu 4:1.

Secara umum, WIKA menggunakan utang sebagai sumber modalnya, tetapi porsi besarnya terdapat pada utang jangka pendek. Meskipun begitu, rasio utang terhadap ekuitas WIKA pada tahun 2019 menjadi 2.23 kali. Menurut penuturan Tumiyana, selaku Direktur Utama WIKA 2019, selanjutnya WIKA sedang melakukan pertimbangan untuk menggunakan ekuitas sebagai sumber dana mengingat rasio utang sudah mencapai 2.23 kali. Adapun kajian yang dilakukan, salah satunya yaitu penerbitan Surat Berharga Perpetual Tahap II.

\section{b. Cost of debt}

Penghitungan biaya utang jangka panjang menunjukkan biaya yang dibebankan kepada Perseroan atas penggunaan dana yang bersumber dari pinjaman jangka panjang. Biaya modal utang sebelum pajak dihitung dengan:

$$
\text { Cost of debt before tax }(K d)=\frac{\text { Interest of long term }- \text { debt }}{\text { Long term }- \text { debt }}
$$

Sumber pendanaan dari utang baik jangka pendek maupun jangka panjang memiliki kelebihan yaitu sebagai pengurang pajak (tax deductable). Hal ini dikarenakan, sebelum melakukan pembayaran pajak, laba yang digunakan telah dikurangi dengan beban dari pendanaan atau beban keuangan. Adapun bunga dari pinjaman termasuk di dalam beban keuangan tersebut. Kemudian, penghitungan pengurangan pajak dalam Tabel 4 menggunakan tarif pajak 25\% yang merupakan tarif pajak kini Pajak Penghasilan (PPh) Badan Pasal 25.

Tabel 4. Cost of Debt After Tax WIKA 2016-2019

\begin{tabular}{|c|c|c|c|}
\hline Year & Kd & (1-Tax Rate) & Cost of Long-Term Debt \\
\hline 2016 & $2.34 \%$ & 0.75 & $1.75 \%$ \\
\hline 2017 & $2.18 \%$ & 0.75 & $1.64 \%$ \\
\hline 2018 & $2.31 \%$ & 0.75 & $1.74 \%$ \\
\hline 2019 & $2.06 \%$ & 0.75 & $1.55 \%$ \\
\hline
\end{tabular}

Berdasarkan Tabel 4, biaya utang jangka panjang tertinggi yaitu pada tahun 2016. Kemudian menurun pada tahun 2017, meskipun utang jangka panjang mengalami peningkatan. Hal tersebut dikarenakan peningkatan bunga berada pada bunga utang jangka pendek. Dikarenakan pada tahun 2017 membutuhkan modal kerja yang tinggi sebagai pendanaan dari aktivitas konstruksi yang tinggi. Sedangkan pada tahun 2018 kembali mengalami peningkatan biaya utang jangka panjang disebabkan penerbitan Komodo Bond. Kemudian pada tahun 2019 biaya bunga mengalami penurunan, dikarenakan berkurangnya aktivitas WIKA pada tahun tersebut. 
Faaza Naima, Ambang Aries Yudanto

c. Cost of equity

Tabel 5. Cost of Equity WIKA 2016-2019

\begin{tabular}{|c|c|c|c|c|c|c|c|c|}
\hline Year & DPR & B & ROE & G & Di & Po & Di/Po & Cost of Equity \\
\hline 2016 & $30 \%$ & 0.70 & 10.70 & 7.49 & 36.72 & 2260 & 0.016248305 & 7.51 \\
\hline 2017 & $20 \%$ & 0.80 & 10.52 & 8.42 & 29.08 & 1550 & 0.018760157 & 8.43 \\
\hline 2018 & $20 \%$ & 0.80 & 14.18 & 11.34 & 42.98 & 1655 & 0.025968121 & 11.37 \\
\hline 2019 & $20 \%$ & 0.80 & 13.64 & 10.91 & 56.51 & 1990 & 0.028395189 & 10.94 \\
\hline
\end{tabular}

Referensi: Diolah dari Laporan Keuangan Tahunan Konsolidasian WIKA 2016-2019

Data dividen payout ratio (DPR), return on equity, dan harga saham (Po) pada saat close price, bersumber dari laporan tahunan konsolidasian WIKA 2016-2019. Sedangkan penghitungan retention rate (b) yaitu 1-DPR. Adapun growth (g) dari dividen didapatkan dari perkalian ROE dengan b. Sedangkan Di merupakan dividen yang diprediksikan pada tahun depannya. Penghitungannya yaitu dengan mengalikan dividen per saham (DPS) pada tahun tersebut dengan $(1+\mathrm{g})$.

Pada DPR hampir tidak mengalami perubahan di setiap tahunnya, yaitu sekitar $20.25 \%$. Keputusan pembagian dividen WIKA mempertimbangkan tingkat pertumbuhan ke depan, rencana ekspansi, laba bersih yang dicapai pada tahun fiskal, serta kewajiban Perseroan untuk mengalokasikan dana cadangan sesuai dengan aturan manajemen yang berlaku dan kondisi keuangan.

Biaya ekuitas tertinggi yaitu pada tahun 2018, bersamaan dengan penerbitan SBP pada bulan Desember 2018. Adapun pembayaran bunga dari SBP tersebut diangggap sebagai pembayaran dividen yang akan mengurangi saldo laba ditahan Perseroan. Sedangkan pada tahun 2016, biaya ekuitas cenderung rendah dikarenakan mendapatkan dana segar dari PMN senilai Rp4 triliun. Kemudian pada tahun 2017 menurun meskipun kegiatan konstruksi sedang masif dilakukan. Hal ini dikarenakan dana modal kerja lebih dominan dibandingkan dana dari ekuitas. Sedangkan pada tahun 2019 kembali menurun bersamaan dengan menurunnya aktivitas konstruksi. 
3. Interpretasi Hasil

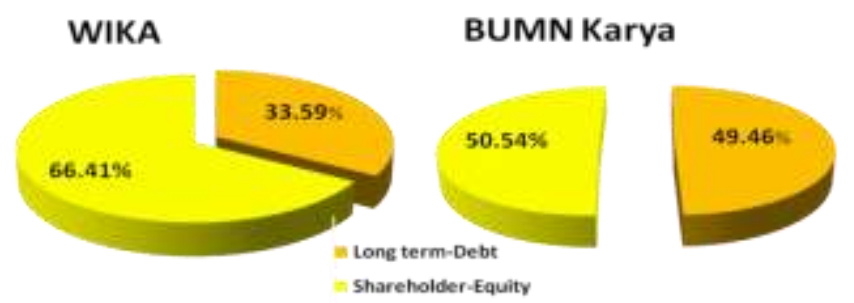

Gambar 2. Struktur Modal Rata-Rata WIKA dan BUMN Karya 2016-2018 Referensi: Diolah Penulis

Selama periode 2016 - 2018, utang jangka panjang WIKA memiliki proporsi yang lebih kecil dari ekuitas, yaitu 33.59\%. Adapun peningkatan utang dalam kebijakan struktur keuangan WIKA yang menitikberatkan pada sumber dana utang, yaitu utang jangka pendek sebagai modal kerja operasi. Sedangkan ekuitas mengalami peningkatan yang besar pada tahun 2016 yang berasal dari PMN dan right issue yang digunakan untuk dana infrastruktur prioritas dan strategis.

Berdasarkan Gambar 2, komposisi struktur modal BUMN Karya hampir seimbang antara utang jangka panjang dengan ekuitas. Pada mulanya, utang jangka panjang BUMN Karya pada tahun 2016, sekitar 36\% dari struktur modal. Kemudian meningkat menjadi $55.76 \%$ dari struktur modal. Sedangkan proporsi ekuitas BUMN karya dalam struktur keuangan, tidak lebih dari 30\% selama periode 2016-2018. Hal ini menandakan bahwa, meskipun kebijakan struktur keuangan WIKA lebih memilih sumber dana dari utang, tetapi WIKA masih menerapkan prinsip kehati-hatian yang ketat terhadap utang jangka panjang.

Penggunaan utang jangka panjang, terkadang memiliki dampak terhadap pembayaran bunga yang lebih besar dan selisih kurs akibat sensitivitas perekonomian global. Selain itu, utang jangka panjang juga menghadapi financial distress serta bankruptcy cost yang tentunya perlu dipertimbangkan tergantung pada selera Perseroan untuk mengambil kebijakan.

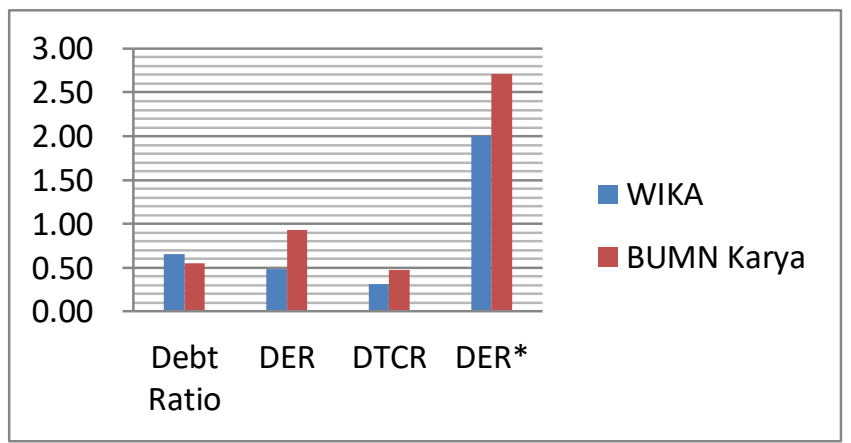

Gambar 3. Solvabilitas Rata-Rata WIKA dan BUMN Karya 2016-2018

Sesuai Gambar 3, utang jangka panjang WIKA masih berada di bawah utang jangka panjang rata-rata BUMN Karya selama 2016-2018. Meskipun begitu, total utang WIKA terhadap aktiva Perseroan lebih besar dibandingkan dengan total utang BUMN Karya. Hal ini dikarenakan WIKA melakukan berbagai proyek dan melakukan ekspansi selama pelaksanaan PSN tersebut. WIKA memaparkan bahwa, meskipun beberapa proyek PSN didanai dari sumber APBN ataupun pinjaman dana nasional dari Pemerintah Jepang dan Tiongkok, WIKA harus mampu menjadi BUMN yang dapat memberikan pengembalian laba yang lebih besar kepada 
pemangku kepentingan. Dalam melakukan ekspansi, WIKA menggunakan metode selective market yang mana hanya mengambil proyek-proyek tertentu saja yang menguntungkan.

Baik DER (jumlah utang jangka panjang terhadap ekuitas) maupun DER* (jumlah utang terhadap ekuitas) WIKA masih berada di bawah rata-rata BUMN Karya. Dalam hal ini, WIKA dipandang masih mampu melakukan pembiayaan melalui utang jika dibandingkan dengan BUMN Karya lainnya. Namun saat ini, DER* WIKA telah mencapai 2.23 kali dari ekuitas. Hal ini membuat pihak WIKA melakukan kajian mengenai sumber dana alternatif, yaitu SBP yang bersifat ekuitas. Pertimbangan tersebut dilakukan untuk menyeimbangkan struktur keuangan WIKA dari sisi ekuitas.

Pengalaman WIKA, atas penerbitan SBP Tahap I pada akhir bulan Desember 2018, diharapkan dapat menghimpun dana yang nantinya dapat terkumpul sekitar 1-2 triliun Rupiah. Akan tetapi, pada pembukaan tersebut baru dapat terkumpul sejumlah Rp600 miliar. Selain itu, SBP tersebut belum dicatat dalam Bursa Efek Indonesia dikarenakan belum adanya regulasi yang mengatur. Dana yang terhimpun dari SBP Tahap I tersebut mayoritas juga berasal dari perusahaan pelat merah.

Sedangkan instrumen keuangan obligasi, pada masa ini lebih sering digunakan oleh BUMN Karya untuk mendapatkan dana modal. Sehingga dapat kita lihat bahwa secara struktur modal, WIKA memiliki alternatif-alternatif pembiayaan yang lebih variatif dibandingkan BUMN Karya rata-rata.

Tabel 6. Nilai Perusahaan WIKA 2016-2019

(dalam ribuan Rupiah)

\begin{tabular}{|c|c|c|c|c|r|r|}
\hline$\underline{\text { Tahun }}$ & $\underline{\text { Laba Usaha }}$ & $\underline{\text { Pajak }}$ & $\underline{\text { Laba Dikoreksi }}$ & $\underline{\text { WACC }}$ & $\underline{\text { Nilai Lindung Pajak }}$ & Nilai Perusahaan \\
\hline $\mathbf{A}$ & $\mathbf{B}$ & $\mathbf{C}$ & $\mathbf{d = b ( 1 - c )}$ & $\mathbf{e}$ & $\mathbf{f = c * ( \text { long } \text { term } \text { debt } )}$ & \multicolumn{1}{c|}{$\mathbf{g = ( \mathbf { d } / \mathbf { e } ) + \mathbf { f }}$} \\
\hline 2016 & $1,730,553,364$ & $25 \%$ & $1,297,915,023$ & $6.21 \%$ & $927,049,676$ & $21,827,452,623$ \\
\hline 2017 & $2,140,364,818$ & $25 \%$ & $1,605,273,614$ & $6.68 \%$ & $1,269,083,098$ & $25,300,125,216$ \\
\hline 2018 & $3,331,157,613$ & $25 \%$ & $2,498,368,210$ & $7.09 \%$ & $3,440,683,822$ & $38,678,599,334$ \\
\hline 2019 & $3,673,507,916$ & $25 \%$ & $2,755,130,937$ & $7.23 \%$ & $3,136,414,306$ & $41,243,342,895$ \\
\hline
\end{tabular}

Sumber: Diolah dari Laporan Keuangan Tahunan Konsolidasian WIKA 2016-2019

Setelah mengetahui posisi struktur modal dan rasio solvabilitas WIKA dengan perusahaan-perusahaan sebanding, yaitu BUMN Karya, perlu dilakukan tinjauan terkait kebijakan internal manajemen terkait penggunaan sumber dana modal jangka panjang. Jika kita lihat dari Tabel 6, nilai perusahaan terus mengalami peningkatan setiap tahunnya, meskipun biaya modal rata-rata juga mengalami peningkatan. Hal ini dikarenakan, laba usaha yang meningkat signifikan pula setiap tahunnya. Di tengah perlambatan Perseroan pada tahun 2019, laba usaha bahkan meningkat 1.12 kali laba usaha daripada tahun 2016. Selain itu, kontribusi dari peningkatan utang jangka panjang terhadap nilai perusahaan, juga tampak pada nilai perlindungan pajak (tax shield) yang terus meningkat.

Peningkatan nilai perlindungan pajak sejalan dengan MM Theory with tax bahwa dengan adanya pajak penghasilan, penggunaan utang akan meningkatkan nilai perusahaan. Sedangkan teori struktur modal tradisional yang mengatakan bahwa nilai perusahaan akan maksimal dengan biaya rata-rata yang minimum, tidak dapat dibuktikan dalam kasus ini.

Penjelasan mengenai biaya rata-rata yang minimum akan memaksimalkan nilai perusahaan, dapat digunakan pada saat WACC saja yang berubah, sedangkan faktor-faktor lain sama atau tidak berubah signifikan. Faktor lain yang dimaksud, yaitu laba usaha (EBIT), 
tingkat pajak, dan utang jangka panjang. Hal ini dikarenakan, perubahan pada faktor-faktor terkait, akan mengurangi dampak dari kenaikan WACC terhadap nilai perusahaan.

Selain itu, menurut Penulis, penghitungan Laba Setelah Dikoreksi tidak menunjukkan kenyataan yang sebenarnya. Hal ini dikarenakan, pajak yang dikenakan pada perusahaan, tidak serta merta dikurangkan dari hasil Laba Sebelum Pajak. Di Indonesia, peraturan pajak perusahaan mengacu pada Undang-Undang Republik Indonesia Nomor 36 Tahun 2008 tentang Pajak Penghasilan. Di dalamnya mengatur objek dan besaran Penghasilan Kena Pajak (PKP).

Adapun penghitungan PKP dilakukan dengan cara mengurangkan penghasilan neto fiskal dengan kompensasi kerugian fiskal. Sehingga, penghasilan yang dijadikan dasar untuk menghitung pajak penghasilan dalam suatu tahun pajak dihitung berdasarkan Penghasilan Kena Pajak, bukan Laba Sebelum Pajak. Sedangkan PPh Badan tersebut, berbeda dengan PPh Final yang telah dikurangkan sebelumnya. Sehingga dalam tulisan ini, yang digunakan adalah PPh Pasal 25 menggunakan tarif Pasal 17 (1) huruf b UU PPh dengan penyesuaian ketentuan ayat (2a).

Dalam Tabel 6, EBIT(1-t) merupakan laba dikoreksi berasal dari EBIT yang dikurangkan dengan perlindungan pajak (EBIT x tax rate). Sehingga dalam hal ini akan terjadi bias terhadap Laba Setelah Dikoreksi dikarenakan tidak menunjukkan nilai perlindungan pajak (asumsi tidak menggunakan utang). Sedangkan terkait nilai lindung pajak (f), sudah sesuai dengan penghitungan berdasarkan proporsi utang jangka panjang. Yang mana seberapa besar perlindungan pajak dalam suatu proporsi peminjaman dana dari utang jangka panjang tersebut.

Ketentuan tersebut, juga mengakibatkan adanya ketidaknormalan Laba Bersih pada tahun 2019. Meskipun Penerimaan Bersih dan Laba Kotor mengalami penurunan, tetapi Laba Bersih yang dihasilkan tetap meningkat dibandingkan tahun 2018. Hal ini disebabkan adanya koreksi pengenaan PKP pada tahun 2019 disebabkan oleh ketidaksamaan perhitungan pajak badan tahun 2018 yang dilaporkan pada laporan audit. Sehingga dilakukan rekonsiliasi tahun 2019 pada PKP Perusahaan Induk dari Rp338,650,904,000,00 menjadi Rp134,499,124,000,00.

Tabel 7. WACC WIKA 2019

\begin{tabular}{|c|l|r|r|r|}
\hline Tahun & Komponen Struktur Modal & Komposisi & Biaya Modal & WACC \\
\hline A & \multicolumn{1}{|c|}{ B } & c & d & e=c*d \\
\hline \multirow{3}{*}{2019} & Utang Jangka Panjang & $39.50 \%$ & $1.55 \%$ & $0.61 \%$ \\
\cline { 2 - 5 } & Modal Saham & $60.50 \%$ & $10.94 \%$ & $6.62 \%$ \\
\cline { 2 - 5 } & Total & $100.00 \%$ & & $7.23 \%$ \\
\hline
\end{tabular}

Referensi: Diolah dari Laporan Keuangan Tahunan Konsolidasian WIKA 2019

Meskipun begitu, Tabel 6 masih dapat digunakan untuk mengukur prediksi perubahan nilai perusahaan dengan asumsi PKP tidak memiliki banyak catatan. Dari tabel tersebut, peningkatan utang jangka panjang WIKA masih memiliki kontribusi meningkatkan nilai perusahaan hinggga WACC sebesar $7.23 \%$, sebagaimana terlihat pada Tabel 7. Adapun peningkatan ekuitas yang proporsional setiap tahunnya, dengan biaya modal yang lebih besar, juga masih mampu meningkatkan nilai perusahaan.

Berdasarkan hal tersebut, dengan WACC 7.23\% (lihat Tabel 7), WIKA mampu meningkatkan EPS pada akhir tahun 2019 sebesar Rp254.74. Angka tersebut meningkat dari tahun-tahun sebelumnya, berturut-turut dari 2016, yaitu Rp162.21,00, Rp134.1,00, dan Rp193.02,00. Sehingga dalam hal ini, kebijakan struktur keuangan WIKA dalam hal menggunakan dominansi utang sebagai sumber dana Perseroan memiliki dampak yang baik bagi nilai perusahaan. Kendati utang jangka panjang tidak dominan dalam jumlah total utang, 


\section{Faaza Naima, Ambang Aries Yudanto}

struktur modal WIKA saat ini masih mampu untuk meningkatkan nilai Perseroan.Meskipun nilai perusahaan terus mengalami kenaikan, margin dari kenaikan tersebut mengalami penurunan yang signifikan. Pada tahun 2017, kenaikan nilai perusahaan yaitu sebesar $15.9 \%$ dan meningkat $52.88 \%$ pada tahun 2018. Namun pada tahun 2019, margin kenaikan hanya sebesar $6.63 \%$.

Hasil dari tinjauan struktur modal ini konsisten dengan simpulan Rustam (2015) bahwa, struktur modal perusahaan sektor industri properti, real estate, dan konstruksi masih berada di bawah batas yang diperkenankan, sehingga perusahaan masih memiliki kapasitas utang yang positif. Penggunaan utang jangka panjang terhadap ekuitas yaitu rata-rata 31\%. Kemudian, rata-rata struktur modal perusahaan sektor industri properti, real estat, dan konstruksi masih tampak belum optimal disebabkan oleh pihak manajemen yang terlalu berlebihan dalam menerapkan prinsip kehati-hatian dalam penggunaan utang jangka panjang.

\section{Kesimpulan}

Simpulan dari tinjauan terhadap rasio solvabilitas WIKA periode 2016-2019, yaitu DER, DTCR, dan TIE WIKA masih berada di batas aman berdasarkan kebijakan manajemen dan rata-rata perusahaan sebanding, yaitu BUMN Konstruksi. Meskipun begitu, debt ratio WIKA rata-rata melebihi 50\% dari aktiva dan rata-rata perusahaan sebanding. WIKA dalam menjalankan Perseroan memiliki tingkat kehati-hatian yang tinggi terhadap penggunaan utang jangka panjang sebagai sumber pendaanaan. Dalam menghadapi pelaksanaan PSN, WIKA memilih untuk melakukan ekspansi dalam rangka mendapatkan laba yang lebih besar untuk menutup kekurangan dari proyek-proyek penugasan. Hal ini tercemin dari porsi swasta dalam kontrak baru dan kontrak dihadapi selalu lebih dominan dibandingkan kontrak dari Pemerintah dan BUMN. WIKA pun masih mampu menjaga kredibilitas struktur modalnya dibandingkan dengan BUMN sejenis dalam lapangan usaha yang sama.

Di sisi lain, biaya modal rata-rata WIKA mengalami peningkatan setiap tahunnya disebabkan oleh faktor-faktor biaya modal masing-masing yang terus mengalami peningkatan ekspektasi dan biaya pinjaman. Meskipun begitu, dikarenakan peningkatan tersebut bersamaan dengan peningkatan penerimaan bersih serta laba usaha, maka nilai perusahaan juga masih mengalami kenaikan. Berdasarkan perhitungan terhadap nilai perusahaan, struktur modal yang optimal WIKA selama periode 2016-2019 yaitu pada tahun 2019 dengan WACC sebesar $7.23 \%$ dan nilai perusahaan Rp41,243,342,895,00. Hal ini sesuai dengan MM Theory yang mana peningkatan utang akan meningkatkan nilai perusahaan apabila terdapat pajak.

Untuk penelitian selanjutnya, analisis terkait struktur modal ini bisa dihubungkan dengan teori lain, seperti agency costs, asymmetric information, interaksi pasar produksi, maupun pertimbangan kontrol perusahaan, sebagaimana disampaikan oleh Harris \& Raviv, 1991. Hal ini penting untuk mendapatkan gambaran struktur modal yang lebih utuh dan menyeluruh pada suatu perusahaan.

\section{Daftar Pustaka}

Aisjah, Siti. 2012. Strategi Diversifikasi Korporat, Disertasi. Malang: Universitas Brawijaya Press.

Atmaja, Lukas Setia. 2008. Manajemen Keuangan. Yogyakarta: Andi Yogyakarta. Arikunto. 2006. Prosedur Penelitian Suatu Pendekatan Praktek. Jakarta: Rineka Cipta.

Brigham, E. F. Dan P. R. Daves. 2004. Intermediate Financial Management. Edisi

Kedelapan. New York: The Dryden Press, Harcout Brace College Publisher.

Damodaran, Aswath. 2012. Investment Valuation. Edisi Kedua. New York: John. 
INOBIS: Jurnal Inovasi Bisnis dan Manajemen Indonesia

Volume 03, Nomor 2, Maret 2020

Faaza Naima, Ambang Aries Yudanto

Harris, M. \& Raviv, A. (1991). The Theory of Capital Structure. The Journal of Finance, $46(1)$.

Hitt, W. D. (1995). The Learning Organization: Some Reflections on Organizational Renewal. Leadership and Organizational Development Journal, 16(8).

Jensen, M. C. (1986). Agency Cost of Free Cash Flow, Corporate Finance, and Take Over. American Economic Review, 76(2), 323-329.

Maftukhah, I. (2013). Kepemilikan Manajerial, Kepemilikan Institusional, Dan Kinerja Keuangan Sebagai Penentu Struktur Modal Perusahaan. Jurnal Dinamika Manajemen, 4(1), 69-81. https://doi.org/10.15294/jdm.v4i1.2425

Mardiyanto, Handono. 2009. Inti Sari Manajemen Keuangan (Teori, Soal, dan Jawaban). Jakarta: Grasindo.

Riyanto, Bambang. 2013. Dasar-Dasar Pembelanjaan. Edisi Keempat. Yogyakarta: Penerbit BPFE.

Rustam, M., 2015. "Penentuan Struktur Modal Optimal Pada Perusahaan Sektor Properti, Real Estate, dan Konstruksi yang Terdaftar di Bursa Efek Indonesia”. Jurnal Ekonomi Bisnis dan Kewirausahaan, Vol.4. No. 1, 94-124.

Sartono, Agus. 2012. Manajemen Keuangan (Teori dan Aplikasi). Edisi Keempat. Yogyakarta: Penerbit BPFE.

Sawir, Agnes. 2003. Analisis Kinerja Perusahaan dan Perencanaan Keuangan Perusahaan. Jakarta: Penerbit Gramedia Pustaka Utama.

Sawir, Agnes. 2004. Kebijakan Pendanaan dan Restrukturisasi Perusahaan. Jakarta: PT Gramedia Pustaka Utama.

Syamsudin, Lukman. 2009. Manajemen Keuangan Perusahaan. Jakarta: Raja Grafindo Persada.

Wangsawinangun, Rizki Zulhilmi, Darminto, dan Nila Firdausi Nuzula. 2014. "Penetapan Struktur Modal Yang Optimal Dalam Upaya Meningkatkan Nilai Perusahaan: Studi Kasus Pada PT Astra Internasional Tbk, dan Anak Perusahaan Tahun 2008-2012”. Dalam Jurnal Administrasi Bisnis Vol. 9, No.2, April 2014.

Zed, Mestika. 2003. Metode Penelitian Kepustakaan. Jakarta: Yayasan Obor Indonesia.

\section{Peraturan Perundang-Perundangan}

Pemerintah Republik Indonesia. 2008. Undang-Undang Pemerintah Republik Indonesia Nomor 36 Tahun 2008 Tentang Perubahan Keempat atas Undang-Undang Nomor 7 Tahun 1983 tentang Pajak Penghasilan. Jakarta: Sekretariat Negara.

Pemerintah Republik Indonesia. 2018. Peraturan Presiden Republik Indonesia Nomor 56 Tahun 2018 Tentang Perubahan Ketiga Atas Peraturan Presiden Nomor 58 Tahun 2017 Tentang Perubahan Kedua Atas Peraturan Presiden Nomor 3 Tahun 2016 Tentang Percepatan Pelaksanaan Proyek Strategis Nasional. Jakarta: Sekretariat Negara.

Pemerintah Republik Indonesia. 2016. Instruksi Presiden Nomor 1 Tahun 2016 Tentang Upaya Percepatan Pelaksanaan Proyek Strategis Nasional. Jakarta: Sekretariat Negara.

Pemerintah Republik Indonesia. 2015. Peraturan Menteri Keuangan Nomor 169/PMK.010/2015 Tentang Penentuan Besarnya Perbandingan antara Utang dan Modal Perusahaan Untuk Keperluan Penghitungan Pajak Penghasilan. Jakarta: Sekretariat Negara. 
INOBIS: Jurnal Inovasi Bisnis dan Manajemen Indonesia

Volume 03, Nomor 2, Maret 2020

Faaza Naima, Ambang Aries Yudanto

Peraturan Otoritas Jasa Keuangan Republik Indonesia Nomor 30/PJOK.04/2019 Tentang

Penerbitan Efek Bersifat Utang dan/atau Sukuk yang Dilakukan tanpa melalui

Penawaran Umum.

\section{Lainnya}

Kementerian BUMN Republik Indonesia. 2017. "Kiprah BUMN Membangun Negeri, Proyek Strategis Nasional BUMN 2017". Diunduh dari

http://bumn.go.id/upload/download img/file download/5a9debb0744f7 20180306081528/8/ \#zoom=z/ 03/06/2020. 